\author{
Journal of Analytic Divinity \\ International Refereed Journal \\ E-ISSN: 2602-3792 \\ Nisan/April 2021/5 (1): ss-pp 150-176
}

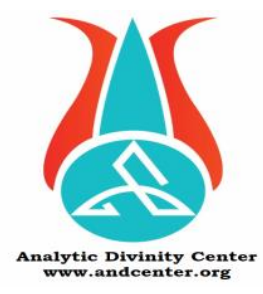

\title{
Kur'an'da Olumsuz Duyguların Kontrolü
}

Control of Negative Emotions in the Qur'an

\begin{abstract}
Büşra Kara
Ankara Yıldırım Beyazıt Üniversitesi İslami İlimler Fakültesi Ankara Yıldırım Beyazıt University Faculty of Islamic Sciences
\end{abstract}

Ankara, Türkiye, busrakara543@gmail.com

https:// orcid.org/ 0000-0001-6172-2072

Makale Bilgisi | Article Information

Makale Türü / Article Type: Derleme Makale/ Review Article

Geliş Tarihi / Date Received: 02 Şubat/ February 2021

Kabul Tarihi / Date Accepted: 21 Mart / March 2021

Yayın Tarihi / Date Published: 15 Nisan /15 April 2021

Yayın Sezonu / Pub Date Season: İlkbahar-Nisan/ Spring-April

DOI: $10.46595 /$ jad.874067

Cite as / Atıf: Kara, Büşra. "Kur'an'da Olumsuz Duyguların Kontrolü", Journal of Analytic Divinity, 5/1 (April 2021): 150-176.

İntihal: Bu makale, iThenticate yazılımınca taranmıştır. İntihal tespit edilmemiştir. Plagiarism: This article has been scanned by iThenticate. No plagiarism detected.

Web: http:/ / dergipark.gov.tr/jad | e-mail to: editorjand@gmail.com

Copyright $($ P Published by Özcan Güngör, Ankara Yıldırım Beyazıt Üniversitesi, İslami İlimler Fakültesi / Ankara Yıldırım Beyazıt University, Faculty of Islamic Studies, Ankara-Turkey. Bütün hakları saklıdır. / All right reserved. 


\section{Öz}

İlk başlarda üzerinde fazla durulmayan duygu kavramı zamanla bir ivme kazanarak araştırılmaya ve hakkında konuşulmaya başlanan bir ifade haline gelmiştir. Çünkü hayatın merkezinde bulunan insanın duygularından soyutlanması ve onlar yokmuş gibi yaşaması mümkün değildir. Kişi duygularını bastırmaya ya da denetim altında tutmaya çalışsa da duygular ilk fırsatını bulduğu zaman ortaya çıkabilir ve bu ortaya çıkış yön değiştirerek de olabilir. Bu sebeple kişilerin duygularından kaçması veya duyguları yokmuş gibi davranması yerine onları tanıyarak onlarla beraber yaşamayı ve onları kontrol altına almayı öğrenmesi gerekir. Kur'an'ın duyguların kontrolü bağlamında inanlardan istediği bazı şeyler vardır. Kur'an, bu isteklerinde bazen doğrudan duyguların kontrolünü hedef alırken bazen de davranışlarla kişilerin duygularını kontrol etmelerini istemiştir. Bu çalışma, Kur'an'ın olumsuz duyguları kontrolü bağlamındaki mesajlarını; kişinin yaratıcıyla arasında kurduğu bağlılık, kişinin ibadetlerine etkisi ve kişinin toplumda kendini doğru ifade edebilmesi bağlamında tarihsel dokümantasyon tekniği ile psikolojik ve sosyolojik olarak açılamaktadır. Sonuç olarak, Kur'an'ın kişilerde doğuştan var olan güvenme isteğinin Allah'a yönelmesi sonucunda kurulan bağlllık ve bu bağlılığın getirileri olan kişilerin sergiledikleri ibadetler ve topluma karşı davranışları gibi pek çok konuda olumsuz duyguları kontrol edebildiği görülmüştür.

Anahtar Kelimeler: Din Psikolojisi, Duygu Kontrolü, Duygu Yönetimi, Olumsuz Duygular, Kur'an

\section{Abstract}

The concept of emotion, which was not emphasized too much at first, gained momentum over time and became a concept that began to be explored and talked about. Because it is not possible for people who are in the center of life to be isolated from their emotions and live as if they do not exist. Even if the person suppresses their emotions or tries to keep them under control, after a while, emotions will emerge when they find the first opportunity, and there is a possibility to make this emergence by changing direction. For this reason, people should learn to live with and control them by getting to know them, rather than running away from their emotions or pretending they don't exist. There are some things the Quran wants from believers in the context of controlling emotions. In these requests, the Quran sometimes aimed directly at the control of emotions, and sometimes wanted people to control their emotions with behavior. This study explains the Quran's messages about the control of negative emotions psychologically and sociologically with the historical documentation technique in the context of the commitment that the person establishes with the creator, the effect on the person's worship, and the person's ability to express himself correctly in the society. As a result, it has been found that the Qur'an can control people's negative feelings in many issues such as the devotion that is established as a result of the innate desire to trust in people, and the prayers and behaviors of people who have the benefits of this devotion.

Keywords: Psychology of Religion, Emotion Control, Emotion Management, Negative Emotions, Qur'an

Journal of Analytic Divinity, https://dergipark.org.tr/tr/pub/jad Volume 5/1 


\section{Giriş}

İnsanlar düşünebilen, seçim yapabilen ve yaşadıkları şeylere tepkiler veren varlıklardır. Hiçbir kişi bir diğeri ile aynı zekâya sahip olmadı̆̆ı gibi olaylar karşısında verecekleri tepkiler veya hissedecekleri duygular da aynı değildir. Kişi kendini madde kullanımı veya münzevi hayat tercihi ile toplumdan soyutlamadığı sürece toplumun içinde bulanacaktır. Bu sebeple toplumun kendisine belirlediği rollere ve normlara uygun olarak davranmalıdır (Fichter, 2016, 22). İnsanlar gerek olumlu gerek olumsuz olmak üzere birçok duyguya sahip olan canlılardır. Sahip oldukları bu duygular içinde bulundukları zaman, mekân ve ruh haline göre farkl1lıklar gösterebilir yani değişebilir. Her duygunun her yerde verilmesi doğru değildir. Bu yüzden duyguların kontrol edilmesi gerekir. Duyguların kontrol edilme sebepleri psikolojik olabileceği gibi toplumun insana belirlediği ve kişilerin davranışlarını sınırlandıran normlar ile rollere uyum sağlayabilmek için sosyolojik de olabilir. Duygu kontrolü insanın kendisiyle başa çıkmasını, kendini daha iyi ifade etmesini ve normlara uygun davranmasına bağlı olarak sosyal çevresinden kabul görmesine yardımcı olur.

Düşünceler duyguları besler ve şekillendirir. Aklımızda var olan düşünce gerçekleşmeye başladığı zaman duygular devreye girer. Yani insanlar bir gün öleceklerini hep bilirler ve bu düşünceye sahiptirler fakat ölüm anının yaklaştı̆̆ını fark edince içlerini korku, pişmanlık ve üzüntü gibi çeşitli duygular kaplamaya başlar. Jules Payot, İrade Terbiyesi kitabında bu konuyu "Çekim gücü yüksek bir metal çubuğun manyetik alanlar için etkisi neyse düşünce de duygular için aynıdır. Hatta katbekat daha güçlü bir şekilde duyguları aynı yöne doğru hizaya sokar, duygusal karmaşayı bitirir, disipline eder." (Payot, 2019, 157) şeklinde bir teşbihle ifade etmiştir.

İnsanların duyguları düşüncelerini etkiler (Frijda ve Mesquita, 2000, 45). Çünkü duygular, düşüncelerden daha güçlüdür (Atay, 1961, 103). Bu sebeple bize geçmişte yaşanan bir olayı veya bir bilgiyi hatırlatmada en çok işe yarayan şey duygularımızdır. Kişi o anda yaşadığ duyguyu hatırladığı zaman aklında o ana gider ve oradaki diğer her şeyi de hatırlar. Bu da duyguların nasıl güçlü ve kontrol edilmesi zorunlu olduğunu bizlere bir kez daha gösterir.

Duyguların dişa vurumu davranışlar ile olur (Tuna, 2018, 31). Bu dişa vurum da sinirlenince eli yumruk yapma, dişleri sıkma gibi çoğu insanda aynı şekilde gerçekleşir. Bu sebeple kişi hareketlerini kontrol ettiği zaman bir nevi duygularını da kontrol etmiş olur. Yani kişi mutsuz olduğu zaman mutluyken yaptığı hareketleri düşünüp uyguladığı zaman ruh hali ve duygu durumu da mutluluğa doğru evrilir. Bununla beraber çok güçlü olan duyguları kontrol altına almamızı sağlayacak diğer gücümüz ise akıldır (Payot, 2019). Zaman içinde sabırlı olarak, aklımızı kullanarak ilerlediğimizde duygularımızı artık 
çözmüş ve onları kontrolümüz altına almış oluruz. Bununla beraber eylemlerin duygular üzerinde etkisi olduğu gibi duyguların da eylemler üzerinde etkileri vardır. Şöyle ki kişi bir işi yapacağı zaman bu işi kendisine sevdirir veya bu işe güzel ve olumlu duygularla başlarsa o işi daha rahat ve daha kolay yapar.

Duygularımıza doğrudan hâkim olamasak da onları kontrol altında tutmaya çalışabiliriz. Yani korkulu bir anımızda aniden o korkuyu unutmamız ve mutluluğa geçmemiz mümkün değildir ama korku miktarını kontrol altına alarak korkunun tüm vücudumuzu etkisi altına almasına engel olabiliriz. Duyguları kontrol edebileceğimiz tek kuvvet "mantık"tır ki o da bayağı zayıftır. Ancak zamanla bir şeyleri çözüme ulaştırır (Payot, 2019, 172). Fakat burada işe Kur'an tarafından baktığımızda kişinin böylesi anlarda gerek Kur'an'ın kendisine belirlediği sınırlarla gerek buradaki gibi korku boyutundan bakacak olursak teslimiyetle duygularını daha rahat kontrol edebileceğini söyleriz. Örneğin kişinin başına korktuğu bir şey geldiğinde kişi içinde bulunduğu durumun mutlaka geçeceğini, şu anda yalnız olmadığını veya mutlaka kendisine bir yardım geleceğini düşünür ve dua ederek sakinleşebilir. Böylece de durumu daha hafif ve rahat bir şekilde atlatır.

Literatüre baktığımız zaman Kur'an'da olumsuz duygu kontrolünü doğrudan ele alan çalışma yoktur. Mevcut olan çalışmalarda daha çok duygu yönetimi ele alınmıştır. Bunlar dışında belirli duyguları ele alan çalışmalar da vardır. ${ }^{1}$ Bu çalışma Kur'an'da insan psikolojisi veya duygularla ilgili olmayıp duyguların kontrolü ile ilgilidir. Bu bağlamda çalışmanın konusu duygu kontrolünün Kur'ânî boyutlarını bilimsel açıdan tahlil etmektir. $\mathrm{Bu}$ probleme bağlı olarak çalışmanın temel amacı duygu kontrolünü bilimsel kaynaklar bağlamında ele alarak Kur'an'da olumsuz duyguların kontrolünü a) kişinin yaratıcıyla arasında kurduğu bağlllık, b) kişinin ibadetlerine etkisi ve c) kişinin toplumda kendini doğru ifade edebilmesi bağlamında tartışmaktır. Çalışmada nitel yöntemin tarihi dokümantasyon tekniği kullanılmıştır.

\section{Kavramsal Olarak Duygu Kontrolü}

Arapçada مشاعر(el-Isfahani, 1997, 456), İngilizcede feeling, sense, emotion kelimeleriyle ifade edilen duygu kelimesi İngilizcede "güçlü zihinsel veya içgüdüsel his" (Allen, 1990, 383), Türkçede "hak duygusu, ahlak duygusu, kişilik duygusu gibi farklı şekilleri olan, olay veya kişilerin insanın iç dünyasında uyandırdığı izlenim, his, duyularla algılama" (TDK, 2005, 580; Ülken, 1969, 88) şeklinde tanımlanmıştır. Genel olarak literatürde yapılmış

\footnotetext{
${ }^{1}$ Konuya ilişkin geniş literatür için bkz.: Yeğin (2010) tarafından kaleme alınan “Öfke Duygusu ve Dinî Açıdan Baş Edebilme Yolları", Pak (2012) tarafından kaleme alınan “Kur'an'ın Duyguları Eğitmesi Bağlamında Öfkenin Kontrolü Meselesi", Günay (2015) tarafından kaleme alınan "Kur'an-1 Kerim’de Gençlerin Duygu Gelişimi ve Eğitimi”, Bolay (1989) tarafından kaleme alınan “Kişide Güven Duygusu ve İslam”, Altıntaş (1983) tarafından kaleme alınan "İslam'da Mesuliyet Duygusu”, Karaca (1997) tarafından kaleme alınan “İnsanın Bazı Güdü ve Duygularının İslami Açıdan Değerlendirilmesi", Gözütok (2010) tarafından kaleme alınan "Çocukta Dini ve Ahlaki Duyguların Eğitimi”, Han (2017) tarafından kaleme alınan “Kur'an Işı̆̆ında Duyguların Eğitimi” isimli çalışmalar konumuza yakın olan çalışmalara örnek olarak verilebilir.
} 
tanımlara bakıldığı zaman her bir tanımda soyut ve göreli bir kavram olan, insan davranışlarının şekillenmesinde önemli bir yer tutan duygu kavramının farklı bir özelliğinin ön plana çıkarıldığı ve ortak bir tanım yapılamadığı fark edilmektedir. Bu tanımlar ise şu şekildedir; Goleman (2016)'a göre duygu, “bir his ve bu hisse özgü belirli düşünceler, psikolojik ve biyolojik haller ve bir dizi hareket eğilimi" dir (Goleman, 2016, 373). Konrad ve Hendl (2003) duygu kavramını "mutluluk, üzüntü, korku, nefret ya da hoşlanma gibi bilinci etkileyen, bilme ve bilinçli irade durumlarını fark etme ve birbirinden ayırmayı sağlayan bir durum" olarak tanımlamışlardır (Çoruk, 2012, 13'ten atfen Konrad ve Hendl, 2003). Barutçugil (2004) duyguyu, "hislerde ve zihinsel tutumlarda fizyolojik değişiklikler ve açılayıcı davranışlarla ortaya çıkan bir hareket" şeklinde tanımlamıştır (Avcı, 2014, 7'den atfen Barutçugil, 2004, 73). Çoruk'a (2012) göre duygu; bireyin hem iç çevresinden hem de dış çevresinden gelen uyaranlar karşısında ilk etapta içsel olarak beliren, sonra da bireyin duruşuna, davranışlarına ve beden ifadesine etki eden yapılandırılmış his ve durumlardır (Çoruk, 2012, 16).

Bu tanımlar çerçevesinde duyguyu genel olarak tanımlayacak olursak duygu; sadece kişiyi değil aynı zamanda kişinin içinde olduğu sosyal çevreyi de etkileyen, insanların algılarını, görüşlerini, etkileşimlerini ve davranışlarını şekillendiren, bireyin gerek iş, gerek aile, gerek sosyal yaşamında ortama uyum sağlamasında ve karar vermesinde ona yardımcı olan, kişinin içsel ve dışsal uyarıcılara karşı önce içinde ortaya çıkıp daha sonra davranışlarını etkileyen hislerdir.

Antik Yunan filozoflarından beri tartışılan, uzun yıllardır sosyolog ve psikologların üzerinde durduğu duygu, hakkında ortak bir kavramsallaştırma ve tanımlama yapılamayan bir kavramdır. Platon, duyguların insanların tüm davranışlarını etkilediği üzerinde dururken; Aristoteles ise duyguların herkeste var olduğunu ama önemli olanın bunları kontrol etmek olduğunu vurgulamıştır (Çakar ve Arbak, 2004, 30; Pelit vd., 2018, 87).

17. yüzyılda Spinoza, Tanrı'nın eşit parçaları olan ruh ile bedenin zorunlu bir birliktelik içinde olduğunu ve bedenin öğrendiği şeyleri duygular aracılığıyla ruha öğrettiğini söylemiştir (Atış, 2015, 144). 18. Yüzyıla gelindiği zaman ise duygularla ilgili düşüncelerin olması gerektiği hakkında görüşler bildirilmeye başlamıştır fakat sanayi devrimi ile rasyonalizmin her şeyi çözebileceği ve aklın duygular üzerinde hâkim olduğu görüşü ortaya atılmıştır (Özdemir, 2017, 7' den atfen Robbins, 2001).

17. yüzyıldan itibaren duygu hakkında konuşulmaya başlansa da nitelikli akademik çalışmaların 1980'den itibaren başladığı görülmektedir. İlk başlarda konuşulmayan, üzerinde fazla durulmayan duygu kavramı 1980'lerden sonra yükselişe geçmiş, o zamana kadar daha çok tutumlar ve davranışlar hakkında konuşulurken artık duygular hakkında daha fazla görüş bildirilmeye ve çalışılmaya başlanmıştır (Bekman, 2016, 5'den atfen 
Koptagel İlal, 1984, 93). İnsanlar toplumun içinde yaşayan ve sürekli gerek canlı gerek cansız varlıklarla etkileşim halinde olduğu için duygularından soyutlanması mümkün değildir. Kendisi üzerinde olumlu ve olumsuz etkilere sebep olan, içinde bulunduğu zaman ve mekâna göre değişen bu duygularını hâkimiyeti altına alarak kontrol etmesi, yönlendirmesi hem yaptığı işten dava fazla verim almasını hem de başarılı ve mutlu bir hayat yaşamasını sağlar (Bekman, 2016).

Duyguların rasyonel düşünme üzerindeki olumsuz etkileri olduğu görüşünün aksine son zamanlarda yapılan araştırmalar sonucunda duyguların rasyonel düşünmeyi olumsuz etkilemek yerine insanların rasyonel düşüncelerini yönettiği ortaya çıkmıştır (Robbins ve Judge, 2012). Çünkü duygular insanlara enerji vererek onları harekete geçirir ve davranışları üzerinde etkilidir. Buna Latincede duygu kelimesinin "motus anima" yani "harekete geçiren ruh" kavramıla ifade edilmesi örnek olarak verilebilir (Karakaş, 2017, 82 'den atfen Cooper ve Sawaf, 2000, 20).

Literatürde ortak bir duygu tanımı bulunmamasına rağmen yapılan tanımların genel olarak insanların hissettikleri duygular ile bunların davranışa dönüşmesi gibi duygunun aynı yönleri üzerinde durduğu görülmektedir (Durmuşoğlu Saltalı, 2010, 14'den atfen Özbayrak,2006). İnsanı birçok yönden ve birçok şekilde etkileyen, yaşamı organize etmeyi, çevreye tepki verebilmeyi sağlayan, temelinde toplumsal kurallar, görüşler, inançlar bulunan duygular yaşanırken onlara eşlik eden bedensel değişimler de vardır. Yani duygular hem bilişsel hem davranışsal hem de fizyolojik niteliklerden meydana gelir. Bu bileşenlerin hangi sırayla ortaya çıktığı konusunda görüş birliği sağlanamamıştır. ${ }^{2}$

Izard (1993) ortak bir tanımın tartışmalara sebep olacağını bu yüzden duyguların çoğunluk tarafından kabul görecek temel özelliklerinin belirtilmesinin daha doğru ve yerinde olacağını söylemiştir (Beyhan Mayda, 2017, 35). Hem kişinin başkalarıyla olan ilişkilerini hem de kişinin kendisi ile olan ilişkisini etkileyen duyguların her ne kadar ortaya çıkışlarında ve yapılarında farklılıklar gözlemlense de birtakım ortak özelliklere sahiptirler. Bu özelliklerden bazılarını şöyle sıralayabiliriz:

Duygular önce bedene yansır yani jest- mimiklerle dışarı yansıtılır; geçicidirler, aynı duyguyu uzun süre yasamak normal değildir; önceden kestirilemezler çünkü duygular irademizin dişında kendiliğinden meydana gelirler; kişiye özeldirler ve bireylerin kişilik yapılarına göre farklılık gösterirler; ifade edilmeleri eğitime, sosyalliklere, ailelere, bölgelere hatta ülkelere göre farklılık gösterebilir; istekleri, hedefleri ve hareketleri etkilerler. Bu özellikler tüm duyguları kapsamaktadır. Olumlu ve olumsuz tüm duygular bu özelliklere sahiptir. Aynı zamanda tüm duygular yaşanılan duruma ve ortama göre

\footnotetext{
2 Duyguların oluşumu konusundaki farklı düşüncelerin temelini duyguların nasıl meydana geldiği ve bedende meydana getirdiği değişimler hakkındaki farklı duygu kuramları oluşturmaktadır. Pek çok kuram olsa da en yaygın olanları James-Lange, Cannon-Bard ve Schachter-Singer kuramlarıdır. Konuya ilişkin ileri okumalar için bkz.: (Tuna, 2018, 26-30).
}

Journal of Analytic Divinity, https://dergipark.org.tr/tr/pub/jad Volume 5/1 
bazen aynı anda hissedilmektedir. Bu özellikleriyle duygular birbirinden bağımsız düşünülemez (Baltaş, 2006, 38; Acar, 2007; Konrad ve Hendl, 2003, 17-18; Güney, 2021).

Ortak özellikleri dışında her duygunun kendine has bir özelliği vardır ve kişi farklı hissettiği her duyguda vücudunda meydana gelen değişim de farklıdır. Kişi sinirlendiği zaman kan akışının ellere, korktuğu zaman ise kan akışının ayaklara yönelmesi buna örnek olarak verilebilir (Aybatan, 2018, 23).

İnsanlar yaşamları boyunca gerek büyük gerek küçük pek çok konuda birçok karar alırlar. Duygular bir konuda sadece akılla beraber karar vermez. Aynı zamanda bazı konularda akıl olmadan sadece duygular ile karar verilir. Çünkü duygular kişinin karşılaştığı durum karşısında hareket etmesini, mantığının algılayamadığı yerlerde, acil karar vermesi gereken durumlarda, tehlike anlarında, zorluklara rağmen hedefe ilerlemede, aile kurmada geçmiş tecrübelerinden yola çıkarak bir karar vermesini sağlar. Bu sebeple duygular kadar duyguların işlevlerini bilmek de insan için önemlidir (Özdemir, 2017).

Duygunun tanımı konusunda olduğu gibi işlevleri konusunda da ortak bir karara varılamamıştır. Frijda (1986) duyguların kişiyi harekete hazırlamak, kişinin gelecekteki davranışlarını şekillendirmek ve kişinin etkin iletişim kurmasını sağlamak olarak üç ayrı işlevi olduğunu (Özdemir Yaylac1, 2006, 39-40); Schrerer ise duyguların; bireyi harekete geçmek için hazırlama, olası davranışları biçimlendirme ve bireyin sosyal ilişkilerini düzenlemeye yardımcı olma olmak üzere üç temel işlevi (Acar, 2007, 13'den atfen Çakar, 2002,4) olduğunu söylemiştir.

Duyguların biyolojik, iletişimsel ve güdüsel olmak üzere üç temel görevi vardır. Biyolojik görevleri, insanların hissettiği duyguları çevresine yüz ifadeleri, beden hareketleri gibi yollarla aktarmasıdır. İletişimsel görevler, kişinin gerek kendi hissettiği duyguyu doğru ifade edebilmesi gerek karşısındaki kişinin duygularını doğru anlayabilmesi gibi kişiler arası iletişimi etkilemesidir. Güdüsel görevleri ise kişinin yaşadığı bir olayda nasıl bir hareket sergilemesi gerektiğini öğretir (Durmuşoğlu Saltalı, 2010, 15-16).

\subsection{Duyguların Sinıflandırılması}

Duyguların tanımlanması konusunda ortak bir karara varılamadığı gibi birçok bileşenden meydana gelen duyguların sinfflandırılması konusunda da ortak bir sinıflandırma mevcut değildir. Bu konuda yapılan birbirinden farklı sinıflandırmalar vardır. Bunlara kısaca bakacak olursak;

Plutchik, insanları ve hayvanları harekete geçiren duyguları sevinç, umut, kabul edilme, korku, üzüntü, hayret, öfke ve tiksinti olarak sekize; Goleman (2016) öfke, korku, zevk, sevgi, şaşkınlık, iğrenme, üzüntü, utanç olmak üzere sekize (Goleman, 2016, 373-374); Cüceloğlu olumlu-olumsuz ve güçlü-zayıf olarak ikiye (Cüceloğlu, 1997); Barutçugil (2004) 
üzüntü, kıskançlık, sevinç-neşe ve korku olmak üzere dörde (Avc1, 2014, 9); Tarhan (2014) temel duygular ve yüksek duygular olmak üzere ikiye (Tarhan, 2014); Sayan (2002) ilki birincil duygular olarak adlandırılan kişinin karşılaştığı olaya aniden verdiği refleksler gibi tepkiler, diğeri ise ikincil duygular olarak adlandırılan olay anında değil daha sonra olay hakkında düşünüldükten sonra ortaya çıkan duygular olmak üzere ikiye (Kervancı, 2008, 30 'dan atfen Sayan, 2002, 1) ayırmıştır.

Duygular bu şekilde sinıflandırılsa da sadece bu duygular yoktur. Duyguların bir araya gelmesi ve harmanlanması ile ortaya yeni duygular çıkabilmektedir. Bu sınıflandırmalarda ele alınan duygular, diğer duyguların ortaya çıkmasını sağlayan ana duygulardır. Bununla beraber duyguların nasıl sınıflandırılması gerektiği konusundaki tartışmalar devam etmektedir (Aybatan, 2018, 25). Daha sonra yapılan araştırmalarda ortaya atılan ve en çok kabul görüp, kullanılan sınıflandırma ise temel duygular üzerinden yapilan olumlu ve olumsuz duygular sınıflandırmasıdır (Kervancı, 2008).

İnsanların varlığının ilk anlarından beri onlara eşlik eden ve hayatta kalmalarını sağlayan duygular içinden kişilerin yaşamak istedikleri ve onlara canlılık veren duygular olumlu duygulardır. Her ne kadar istendik olsalar da olumlu duyguların da miktarları ve şiddetleri insanlar için önemlidir ve kişilere zarar vermemesi için kontrol edilmelidir. Olumlu duyguların kişilere katkıları ise şu şekildedir; kişinin kendisine ve çevresine duyduğu güveni arttırarak kişinin çalışma isteğini arttırır, kişinin hem iş hem de özel hayatında başarılı olmasını sağlar (İşeri, 2019, 12' den atfen Barutçugil, 2004, 11; Kervancı, 2008, 35). Bu duygulara ümit, haz, sevgi, mutluluk ve sabır örnek olarak verilebilir. Fakat bu duygular çalışmanın kapsamına girmediği için detaylı olarak açıklanmayacaktır. ${ }^{3}$

Olumlu duygular dışında kalan ve çalışmanın kapsamına giren diğer grup ise olumsuz duygulardır. Mutsuzluk ve özgüven eksikliği yaratan korku, öfke, üzüntü gibi olumsuz duygular bireyin sadece kendisini değil çevresini de olumsuz algilamasına sebep olduğu için çevresini de olumsuz etkiler (Çeşitcioğlu, 2003, 135-136).

Olumsuz duygulardan birincisi öfkedir. Bireylerin temel duygularından olan öfke, olumsuz duygular içerisinde yer almaktadır. Kişiler haksızlığa ve saygısızlığa uğradıklarını düşündüğünde, istediklerini elde edemediklerinde, kavga ettiklerinde kendini gösteren öfke duygusu, örneklerden de anlaşılacağı üzere kişinin haz almasını engelleyen bir durum veya kişi ile karşılaştığı zaman ortaya çıkmaktadır. Bu çevresel etmenlere ek olarak kişisel yaşamla ilgili olan uykusuzluk ve yorgunluk gibi etmenlerde öfke hissedilmesine yol açar. Bununla beraber kişi öfke hissettiği zaman vücudunda birtakım biyolojik değişiklikler de olur (Goleman, 2016, 33; Kervanc1, 2008, 32). Uygun şekilde ifade edildiğinde gayet doğal ve sağlıklı olan öfke duygusu eğer kontrol edilemezse yıkıcı bir hal alarak hem kişiye hem içinde bulunduğu sosyal çevreye hem de yaşam kalitesine birçok zarar verir. Bu sebeple bu

3 Olumlu duygulardan mutluluk, sevgi ve haz için bkz.: (Çetinkaya, 2006, 40), (Kervanc1, 2008, 36-37), (Tarhan, 2010, 105, 65), (Goleman, 2016, 33).

Journal of Analytic Divinity, https://dergipark.org.tr/tr/pub/jad Volume 5/1 
kadar yüksek ve güçlü olan öfke duygusu kontrol edilmelidir çünkü doğru ifade edilemeyen öfke, bireylerde kalıcı hasarlar meydana getirebilir (Kervanc1, 2008, 33).

Olumsuz duyguların ikincisi üzüntüdür. Çoğunlukla bireydeki öfke duygusu etkisini kaybettikten sonra ortaya çıan üzüntü bir diğer olumsuz duygudur çünkü insanlar psikolojik dengeleri bozulduğunda ilk olarak kayg1 ve üzüntü hissederler. Üzüntünün asıl görevi kişinin içinde bulunduğu duruma ayak uydurarak bu süreci en az hasarla ve doğru bir şekilde geçirmesini sağlamaktır. Kişinin enerjisini azaltan üzüntü duygusu eğer uzun süreli olur ve kişiyi depresyona yönlendirirse kişi kendini çevresinden soyutlar ve hayattan zevk almamaya başlayarak içine döner. Bu süreçte yaşadığ1 şeyleri değerlendirerek yavaş yavaş enerjisini arttırmaya ve bundan sonrasını planlamaya başlar (Tarhan, 2010, 192; Goleman, 2016, 34).

Olumsuz duyguların üçüncüsü kaygıdır. İçerisinde sıkıntı, üzüntü, korku vb. birçok duyguyu barındıran kaygı, endişe duygusuyla başlar ve kişinin sürekli kötü bir şey olacağını düşünmesi halidir. Kişinin olması muhtemel tehlike ve tedbirlerle baş etme yolu olan kaygı, kişileri bu muhtemel sorunlara çözüm üretmekten çok aynı şeyleri tekrar tekrar düşünerek bu düşüncelerine sıkışmalarına yol açar. Kişinin kaygı hissetmesinin belli bir sebebi yoktur. Çünkü kişi etrafında olan şeylere farklı bir gözle bakar ve kimsenin tehlike olarak görmediği şeylerin bile tehlikeye yol açacağı düşüncesine sahiptir. Tedirginlikten panik haline kadar farklı boyutları vardır. Bireylerin bu düşünceleri ve kafalarında kurdukları muhtemel tehditlerle mücadele etmelerine yardımcı olan kaygı eğer belirli bir sınırda olursa kişinin hayatına olumlu katkıları da olabilir. Çünkü kaygılı bireyler tüm ihtimalleri hesaba kattıkları için harekete geçerler ve verimli işler yapabilirler ama eğer kaygının miktarı artarsa işte o zaman kişiyi olumsuz etkiler ve kişi dikkatini toplayamaz ve enerjisini tam olarak kullanamaz (Goleman, 2016, 100-101; Özer, 2003, 76; Kervanc1, 2008, 34 'den atfen www.yasamsuyu.com).

Olumsuz duyguların dördüncüsü ise utanmadır. Cürcani tarafından "kınanma korkusuyla bazı şeyleri yapmaktan nefsini tutma ve o işi terk etme" (Cürcani, 2003, 158) olarak tanımlanan haya yani utanma, kişilerde olması beklenen özelliklerden biri olmakla beraber kişiye rahatsızlık veren bir duygudur. İçerisinde mahcubiyet, üzülme, suçluluk gibi birçok duyguyu barındırır. Utanma duygusu yoğun bir şekilde yaşandığı zaman kişinin özgüvenini kaybetmesine, kendini sosyal yaşamdan soyutlamasına, yaratıcılıktan uzaklaşmasına, derslerinde ve iş hayatında başarısız olmasına, yeniliklerden korkmasına ve bu korkunun zaman içinde kişinin benliğini ve ruhunu sararak iç dünyasına hükmeden ruhsal bir sendrom haline dönmesine yol açar ve kişi normal hayatında toplumun değerlerine ve sosyal ilişkilerine ters düşecek hareketler sergiler. Bu sebeple utanma duygusu dengede tutulmalıdır (Goleman, 2016). 


\subsection{Psiko-Sosyal Açıdan Duygu Kontrolü}

Doğuştan gelen ve insanların psikolojik yapılarının temeli oluşturan duygular, insanların sağlıklı ve dengeli yaşamasını sağlarlar. Duygular her insanda bulunmasına rağmen her insanda aynı şekilde dışa vurulmaz, insanların içinde bulundukları duygu halini ifade etmeleri ve bunu davranışlarına yansıtmaları farklı kişiliklere sahip oldukları için farklı şekillerde olur. İnsanların günlük yaşamlarında çevreden aldıkları uyarıcılara verecekleri tepkileri de duyguları yönlendirir. Eğer kişi bir nesne veya kişiye karşı sevgi duyuyorsa ona karşı olumlu tepkiler sergilerken; eğer nefret ve öfke gibi duygular besliyorsa olumsuz tepkiler sergilemektedir. İnsanların sergiledikleri bu davranışlar sevgi kaynaklı olduğu zaman toplumda kabul görürken, öfke kökenli olduğu zaman ise toplum tarafından kabul görmemektedir.

Yaşamımızın vazgeçilmez birer parçası haline gelen, harekete geçmemiz için gerekli olan enerjiyi sağlayan, temel psikolojik (sevme, güvenme vb.) ve fizyolojik (uyuma, beslenme vb.) ihtiyaçlarını karşılamak için insanları yönlendiren, doğru kararlar vermeyi sağlayan en önemli deneyimlerimizden olan duygularımız davranış ve düşüncelerimizin merkezinde yer almaktadır. Karşılaştı̆̆ı herhangi bir durumda kişinin nasıl tepki vereceğini o anda hissettiği duygular karar vererek insanları yönlendirir. Bu yüzden gerek kişinin kendisini anlamasında gerek çevresindekileri doğru anlayarak iletişim kurmasında oldukça etkili ve önemlidir. Çünkü kişi nasıl hissederse çevresine de o şekilde davranır ve çevresinin de bu duygudan etkilenmesine sebep olur. Bu sebeple kişi duygularından tamamen kaçmak veya tamamen duygularına yönelmek yerine duygularını zamana ve mekâna göre kontrol etmelidir.

Duyguları tamamen yok sayıp yaşamaktan kaçınmak birey için zararlı bir hale gelebilir. Çünkü duygularını yaşayamayan ve bunları aktaramayan kişiler yaşamlarını bir baskı altında yaşamış olurlar bu ise onların hem bedenen hem de ruhen yok olmasına ve karanlık bir yaşam sürmelerine sebep olur. Bu kararmanın yaşanmaması için duygular dışa vurulurken de dikkatli olunmalı ve aşırıya kaçılmamalıdır. Çünkü kişi duygularını aşırı yaşadığı zaman karşısından yeterli karşılığı alamadığı, anlaşılmadığı gibi hislere kapılarak yine kendine zarar verebilir.

Goleman, kişinin hayatında kullandığı iki zihni olduğundan bahsetmektedir. Bunlardan ilki kişinin rasyonel düşünmesini, mantıklı ve planlı kararlar vermesini sağlayan halk diliyle "kafa" yani akılcı zihindir. Diğeri ise planlanmamış olarak, ani şekilde sergilenen davranışların kaynağı olan, sezgilerle hareket etmemizi sağlayan halk diliyle "kalp" yani duygusal zihindir. Önemli olan kişinin bir şeye tepki vereceği zaman bu iki zihni aynı seviyede kullanabilmesidir ki bunu da duygu kontrolü ile sağlayabilir (Goleman, 2016, 35).

Kişinin iç dünyalarının yansıması olan, hayatta kalmasına, karar vermesine, harekete geçmesine, gerek bugününü gerek yarınını şekillendirmesine ve planlamasına yardımcı olan, bireyin beynine gönderdiği sinyaller aracılığıyla kişinin sergileyeceği davranışları

Journal of Analytic Divinity, https://dergipark.org.tr/tr/pub/jad Volume 5/1 
yönlendiren duygular kaybedilirse kişi yaşamın anlamını da kaybeder (Beyhan Mayda, 2017, 37). Bu sebeple kişi kendini hissettiği duygulardan soyutlayamaz, onlar yokmuş gibi davranamaz fakat duygularını tanıyarak, hangi duygunun ne zamanda ve ne şekilde ortaya çıktığını, hangi duygunun kendisinde ne gibi tepkilere sebep olduğunu öğrenir ve duygularını kontrol edebilir, yönetebilir. Çünkü duygular kişinin davranışlarını yönetmekle beraber kişinin davranışlarının anlamlarını öğrenmesine de yardımcı olur ve eğer yaşamımızın her alanında önemli bir yere sahip olan duygular kontrol edilmez veya yönetilmezse zamanla sorunlara yol açabilir (Akça Erdoğan, 2018, 30).

Tarhan (2014)' in “Duygular ata benzer ve kendi haline birakılırsa, sorumsuz, sinırsız bir şekilde hareket etmek ister" şeklindeki ifadesi duyguların kontrol edilmesi gerektiğine, Yazıcı (2007) tarafından vurgulanan Descartes'in "duygular uygun alışkanlıkların kazanılmasıyla kontrol altına alınabilir ve yönlendirilebilir" şeklindeki ifadesi ise duyguların kontrol edilebileceğine işaret etmektedir (Yazıcı, 2007, 7).

Duyguların işlevlerini yerine getirebilmeleri için kişinin duyguları tanıması ve eğitmesi gerekmektedir. Kişi duygularını tanıdığı zaman kendi bilincini de tanımış olur. Kendi bilincini tanıyan insan ise karşılaştığı olaylara daha doğru ve kendisi için daha yararlı kararlar verebilir. İnsanların her şeyi kontrol etmesi mümkün değildir ama yaşamlarını düşünce ve davranışları üzerine yapılandıran insanların, duygularını iyi tanıyıp onları kontrol etmeleri mümkündür (Avc1, 2014, 8' den atfen Barutçugil, 2004, 82). Duygularını ve davranışlarını tanıyıp, kontrol edebilen kimseler, duygusal yönden sağlıklı kimselerdir (Gençoğlu ve Yılmaz, 2013; Abdullah vd. 2013, 365).

Henri Bergson'un “Bilimden, sanattan yoksun insan toplulukları geçmişte var olmuştur. Şimdi de vardır. Fakat dinsiz bir toplum hiç bir zaman var olmamıştır" ifadesi dinin insanlar hayatında ne kadar önemli ve kesin bir yere sahip olduğunu ifade eder (Bergson, 1962, 127). Bu sebeple insanlar hakkındaki bir konu olan duygu kontrolünü ele alırken insanlara hitap eden ve onları çok iyi tanıyıp, onlar hakkında çok iyi analizler yapan Kur'an-1 Kerim'e bakmakta fayda vardır (el-Mearic 70/19; el-İsra 17/11; en-Nisâ 4/28; elEnbiyâ 21/37).

\section{Kur'an'da Olumsuz Duyguların Kontrolü}

İnsanların sergilediği davranışların kaynağı duyguları, düşünceleri, inançları ve içinde bulundukları toplumun kurallarıdır (Dodurgalı, 1995, 51). İçerisinde insanların mutluluğu için ögüt (el-Müddessir 74/54-55), tavsiye (en-Nahl 16/98), emir (el-Kalem 68/48) ve yasaklar (ed-Duhâ 93/9) gibi ihtiyaç duyacakları her şeyi barındıran bir kitap olan Kur'an, insanların düşünce ve davranışlarını şekillendirmiştir (Vural, 2011, 128). Kur'an insan eğitiminde sadece akla yönelmemiş, o kişileri eğitirken onların hem akıllarını hem de duygularını esas almıştır (Uludağ, 1985, 178; Y.Ş. Yavuz, 1983, 104). İnsanların iyi 
duygulara sahip olmasını isteyen Allah, insandaki bu duyguların nasıl olması gerektiğini Kur'an' da belirtmiştir (Han, 2017, 88).

Duyguları yok edemeyiz ama yönlerini değiştirebiliriz (Gözütok, 2010, 807). Duyguları kontrol etme onlar ortaya çıkmadan önce onları tanıyarak yapabileceğimiz bir şeydir. Nasıl ki insanlar başlarına bir hastalık gelmeden önce tedbirler alıp hastalıklara hazırlanıyorlarsa aynı şekilde kendilerini yaşamaları muhtemel duygulara onları tanıyarak hazırlayabilirler. Veya insanlar tabiatları gereği öfkelenebilir. Bir müminin yapması gereken öfkelenmemek değil öfkelendiği zaman öfkesini kontrol edebilmektir. Kişinin duygularını kontrol etmesi için dinin ona sunduğu bazı sebepler ve motivasyonlar vardır. $\mathrm{Bu}$ motivasyonların en önemlisi dünyada yaptığı her şeyin ahirette karşılığını alacağ1 düşüncesidir (Kasapoğlu, 2016, 76). Kişiler pekiştirilen davranışlarını sergilemeye devam ederken cezalandırılan davranışlarını sergilemekten vazgeçerler. Bu sebeple Kur'an'da inananlar azap ile tehdit edilmiştir. Örneğin yalan, zulüm, gıybet gibi eylemlerin cezası bu dünyada verilmese bile ahirette karşıllğı olacağı düşüncesi insanların kendilerini bunlardan alıkoymasına yol açar.

Araf Suresi 7/172' de ve Rûm Suresi 30/30-31' de ${ }^{5}$ yer alan ifadelere bakıldığ zaman dinin insanların doğuştan içlerinde olduğu yani fitratlarında bulunduğu söylenmektedir. Çünkü var olan düzen ve gerçeklikler kişileri bu düzen arkasında bir yaratıcı olması gerektiği düşüncesine itmektedir (Yapıc1, 2003, 129). İnsanlar bu düşünce sonucunda kendilerine kutsallar bulurlar ve kutsallar ile duygusal bir bağ kurarlar. Bireylerin yaşamlarında bu kadar etkin olan duygularının, dini yaşamlarında pasif olması gibi bir şey söz konusu olamaz.

İnsanların dindarlık düzeyleri içlerinde bulundukları zaman, mekân ve şartlara bağlı olarak değişim gösterebilir. Örneğin aile, dini inanç ve uygulamaları çocuğa öğreterek ondaki dini duyguyu güçlendirebileceği gibi çocuğu dinden uzaklaştırarak ondaki dini duyguyu köreltebilir (Güngör, 2012, 88). Bunlara ek olarak kişinin dindarlık boyutunu etkileyen en önemli unsur içinde bulunduğu duygu durumlarıdır. Çünkü inançlar içerisinde pek çok duygusal süreç barındıran tecrübelerdir. Bununla beraber inançların duygusal boyutları diğer boyutlardan daha çok etkilidir. Duygular kişilerin en çok dini yaşantıları ve dini yaşantıları yoluyla sergiledikleri davranışlarını etkilemektedir.

Dini duygular bireylerin hayatlarının çok farklı yönlerini etkilemektedir. Örneğin din kişiye nefretten çok sevgiyi, kızgınlıktan çok güler yüzlülüğü tavsiye eder. Bunlara ek olarak kişi inançlarının gereği olarak günlük yaşantısının her alanında kendinden beklenen

\footnotetext{
${ }^{4}$ Rabbin Âdemoğullarn'ndan -onların sırtlarından- zürriyetlerini alıp bunları kendileri hakkındaki şu sözleşmeye şahit tutmuştu: Ben sizin rabbiniz değil miyim? "Elbette öyle! Tanıklık ederiz" dediler. Böyle yaptık ki kıyamet gününde, "Bizim bundan haberimiz yoktu" demeyesiniz (el-Araf 7/172).

$5 \mathrm{O}$ halde sen hanîf olarak bütün varlı̆̆ınla dine, Allah insanları hangi fitrat üzere yaratmışsa ona yönel! Allah'ın yaratmasında değişme olmaz. İşte doğru din budur; fakat insanların çoğu bilmezler. Hepiniz O'na yönelerek O'na karşı gelmekten sakının, namazı kılın; müşriklerden olmayın (er-Rûm 30/30-31).
}

Journal of Analytic Divinity, https://dergipark.org.tr/tr/pub/jad Volume 5/1 
duygu durumuna göre davranışlar sergiler. Ya da içinde bulunduğu duygu durumu dini yaşantısını etkileyebilir (Koçak, 2016, 36).

Kişilerin dine olan inançları farklı zamanlarda ve farklı şekillerde ortaya çıkabilir. Dinin kişiler üzerindeki etkileri de olumlu ve olumsuz olabilir. Mesela kişinin yaratıcıya karşı hissettiği duygular ve bağl1lık derecesi onun zorluklarla başa çıkmasında kendisine yardımcı olduğu için olumlu sayılırken, kişinin kendi bir şeyler yapmak zorunda hissedip bunları gerçekleştiremediği zaman kendisini suçlaması ise olumsuz yönlerindendir.

Kur'an-1 Kerim insanları bir tasavvuf terimi olarak insân-1 kâmil (الإنسان الكامل) yani mükemmel bir insan diğer bir deyişle insan olarak doğan kişilerin insan olarak kalmasını, ahlaklı bir şekilde hareket etmesini amaç edinmiştir. ${ }^{6}$ Bu sebeple insanların olumsuz duygularını ve davranışlarını yönetmiş ve onlara bir yol göstererek onları eğitmiştir. Onlara yapmaları ve yapmamaları gerekenlerin neler olduğunu söylemiş, hangi durumlarda nasıl davranmaları gerektiğini de açıklamıştır. Gerek ahlakla gerek hukukla kontrol altına aldığı konulara hırsızlık, zina, cinayet, fakirlik-zenginlik, iftira gibi durumları örnek olarak verebiliriz. Özellikle Kur'an'ın indiği Arap toplumuna baktığımız zaman Kur'an toplumda var olan kabilecilik anlayışına bir son vermiş ve onlara Hucurat Suresi 13.ayette "Ey insanlar! Şüphesiz sizi bir erkek ile bir dişiden yarattık, tanışasınız diye sizi kavim ve kabilelere ayırdık..." (el-Hucurat 49/13) diyerek üstünlük duygusunu ortadan kaldırmış olması Kur'an'ın yani dinin insanların olumsuz duygularını kontrol ettiğine dair çok açık bir örnektir. Bu konuya verebileceğimiz bir diğer örnek ise birçok insanda bulunan ve çok keskin bir duygu olan kibirdir. Kur'an insanlarm kibirlenmemesi ve kibirlenenlerin sonunun nasıl olacağı konusunda birçok yerde (en-Nisâ 4/172-173; en-Nahl 16/23, 29; elİsrâ 17/37; el-Lokmân 31/18; es-Secde 32/15; ez-Zümer 39/60, 72; el-Mü'min 40/35,76 ) örnekler verilmiştir.

Kur'an'ın olumsuz duygulara olan bu müdahalesi kişilerin üstün bir varlık olan yaratıcıya bağlanmalarıyla başlar. Kişiler yaratıcıya bağlandıktan sonra O'nun kendilerinden istediklerini yapmaya çalışırlar. Bu bağlanma kişinin ibadetleri veya toplumsal hayatlarında kendilerini ifade edebilmeleri gibi pek çok alanda inananların hayatlarına müdahil olur.

\subsection{Kişinin Yaratıcısıyla Arasındaki Bağlılık}

Bağlanma, gelişim için kritik bir dönem olan bebeklik döneminde ebeveyn veya bakıcıya bağlanma ile başlar. Özellikle bebeğin annesine duyduğu bağlllık güven duygusunun oluşmasında etkilidir. Anne veya bakıcı ile kurulan bu bağlılık sonucunda çocuğun davranışları anne veya bakıcı tarafından şekillendirilir. Bununla beraber çocuk,

\footnotetext{
6 Aslında insan-1 kamil felsefi tasavvufi bir düşünce olsa da, olgun insan anlamında kullanılmasında beis yoktur. Detaylı bilgi için bkz.: (Yılmaz, 2019, 149).
} 
annesi veya bakıcısına karşı hissettiği duyarlılık ile onların sergiledikleri davranışlar sonucunda hareketlerini oluşturur. Anne ya da bakıcı ile bebek arasında oluşan bu duygusal bağlanma sonucunda tehlikeli durumlarda bu iki kişinin kendini koruduğunu fark eden bebek ile anne veya bakıcı arasında güvenli bir bağlanma ve bebekte güvenlik duygusu oluşur (Kirkpatrick, 2006, 136).

Daha sonraki dönemlerde ortaya çıkan ve bireyin yaşamındaki en kritik bağlanmalardan birisi de dini bağlanmadır. Erich Fromm'un insanda başlangıçtan beri ayrılmaz bir şekilde bulunduğunu söylediği bir şeye bağlılık ve yönelme sistemi hayat boyu değişik şekillerde devam etmektedir (Peker, 2003, 79). Sevgi ve güvene bağlı olarak bireyin ilk gününden beri var olan bağlanma, zamanla kişinin iç bütünlügüünü oluşturmasına yardım eden bir inanca bağlanmasına yol açar (Mehmedoğlu, 2005, 25). Birey dini bağlanmada var olan gerçeklikler içerisinde en üstte bulunan Tanrı'yı bağlanma figürü olarak kabul eder. Çünkü yaşamda kendini güvende hissetmek ve karşılaştığı zorlukların üstesinden gelebilmek için aradığı desteği aşkın bir güç olan Tanrı'dan alır. Bazı araştırmacılara göre bağlanma duygusu normalde bireye zarar veren bir duyguyken bağlanılan varlık Tanrı olduğu zaman bu birey için olumlu sonuçlar doğurabilir. Çünkü normalde birey bağlandığ 1 kişi veya nesnenin gitmesi ile mutsuzluğa ve derin bir üzüntüye bürünecekken Tanrı'ya bağlandığı zaman hem kendine yeni bir bağlanma figürü bulmuş hem de gitmeyecek bir varlığa bağlanmış olur ve bağlanma bitmez.

Bağlanma hissinin temelinde sevgi bulunur (Bovet, 1958, 25). Sevgi, Allah'a karş1 hissedilen bağl1lık ve güvenin zorunlu öğesidir ve eğer birey ile kutsal arasındaki ilişkide sevgi bulunmazsa bağlılık ve güven de bulunmaz. Bu sebeple daha genel bakıldığı zaman sevgi, inancın temel öğelerinden birisidir denilebilir (Koçak, 2016, 46). Kişinin Allah'a duyduğu bu sevgi sonucunda dini uygulamaları ortaya çıkar. Çünkü Allah'ı seven ve ona inanan kişi, Allah ile ruhen bütünleşebilmek amacıyla davranışlarını şekillendirir (Yapıcı, 1997, 224). Bu açıdan bakıldığı zaman normalde insanın hayatı üzerinde çok etkili olamayan sevginin, Allah sevgisi sonucunda gelen dini inanç ile kişinin hayatını şekillendirdiği görülmektedir. Bununla beraber kişinin Allah'1 sevmesine ek olarak Kur'an1 Kerim'de Allah'ın kimleri sevip kimleri sevmediği de yer almaktadır ve bu bilgiler doğrultusunda inananlar davranışlarını şekillendirmektedir. Allah'ın sevmediği kimseler Kur'an'da Allah'ın kendisine inanıp itaat etmeyen kâfirler (el-Âl-i İmrân 3/32, er-Rûm 30/45), zalimler (el-Âl-i İmrân 3/57, eş-Şûrâ 42/40), aşırıya kaçarak ölçüsüz davrananlar (el-En'âm 6/141) şekilde zikredilmektedir.

Sözlükte iman, "kalp ile tasdik etmek” (Cürcani, 2003, 99) olarak tanımlanır. Kişinin iman etmesinin temelinde kendisine güveneceği ve bağlanabileceği birini arama isteği yatmaktadır. Sevgi ve güven duygusu olmadan kişinin ne bir yaratıcıya güvenip bağlanması ne de çevresiyle sağlıklı ilişkiler kurması mümkün değildir (Türk, 2014, 151). Günümüze kadar pek çok din ve inanç ortaya çıkmıştır. Bunların hepsi birbirinden farklı

Journal of Analytic Divinity, https://dergipark.org.tr/tr/pub/jad Volume 5/1 
olsa da ortak bir noktaları vardır. Bu ortak nokta ise inananları inanılana yönelten içsel motivasyonlarıdır. Dini tecrübelerin hepsinin duygusal bir yönü vardır (Koçak,2016, 25).

TDK sözlüğünde "Korku, çekinme ve kuşku duymadan inanma ve bağlanma duygusu, itimat" (TDK, 2005, 816) anlamlarına gelen güven, bağlanma ile ilişkili olan bir diğer duygudur. İnsanın temel psiko-sosyal ihtiyaçlarından olan güven, kişiyi huzur ve başarıya götürür fakat kişi kendini güvende hissetmezse kaygı ve başarısızlık ile karşılaşır (Sert, 2008, 198). Kur'an Peygamberlerin insanlarla sağlıklı bir bağ kurmaları için onların güvenilir olmaları üzerinde durmuştur ve tüm peygamberlerin güvenilirlikleri onların vasıfları olarak Kur'an'da zikredilmektedir. Kur'an'da Lut (eş-Şuara 26/162), Şuayb (eşŞuara 26/178), Nuh (eş-Şuara 26/107), Hud (eş-Şuara 26/125) ve Salih (eş-Şuara 26/143) peygamberlerin kavimlerine gönderilen güvenilir elçiler oldukları belirtilmektedir. Hz. Muhammed'in peygamber olmadan önce bile Mekkeliler tarafindan "el-Emîn" yani "güvenilir insan" olarak anılması peygamberlerin güvenilirliklerin kendilerinde peygamberlikten önce de bulunduğunu göstermektedir. Bununla beraber Allah kendisine yürekten inanan Peygamberine ümitsizliğe ve endişeye düştüğü zamanlarda güven duygusunu vermiştir (et-Tevbe 9/40) (Karaman vd., 2012, 11).

Kişide yaratıcının kontrol ettiği olumsuz duygulara; öfke (el-Al-i İmran 3/134; eşŞurâ 42/37), üzüntü, ümitsizlik (el-Yusuf 12/87; el-Hicr 15/55-56; ez-Zümer 39/53), kıskançlık (el-Felak 113/5), kindarlık (el-Mâide 5/2, 8), kibir (en-Nisâ 4/173; en-Nahl 16/23, 29; el-İsra 17/37; ez-Zümer 39/60) ve böbürlenmek (en-Nisâ 4/36; el-Hadîd 57/23) gibi duygular örnek olarak verilebilir.

İnsanların algılarını yönlendirmeleri ve hayat şartlarını kabul etmeleri üzerinde etkili olan dua ve dini bağlılık, kaygı ve stres gibi olumsuz duygulara karşı bir teselli kaynağıdır (Yapıc1, 2013, 116-117). Kişinin dindarlığı ister bireysel ister kurumsal olsun kişinin depresyona girmesini de engeller (Yapıc1, 2005, 134).

Din kişilerin duygu, düşünce ve davranışlarını bazen doğrudan bazen de dolaylı olarak kontrol etmektedir (Yapıcı, 2005, 138). Kur'an insandan yukarıda da belirtildiği gibi birtakım şeyler ister. Bunların içinde doğrudan insanların duygularını kontrol etmelerini isteyen emirler de vardır (el-Al-i İmran 3/134), dolaylı olarak sergileyecekleri davranışlar için duygularını kontrol etmeleri gereken emirler de vardır (el-Lokman, 31/18-19) (Kuşeyri, $1999,181)$.

Kişi bu emirleri yerine getirdiği zaman dinin yani Allah'ın dediklerini yapmış olacak ve böylece yaratıcı ile arasında bir etkileşim başlayacaktır. Buna ek olarak kişi yaratıcı ile arasında başlayan ilişkiler sonucunda oluşan bu bağlılık ile duygusal olarak da bir ilişki kuracaktır. Kurduğu bu duygusal bağ hayatının her anında yanında olan, onu asla yalnız bırakmayan ve ihtiyacı olduğu zaman ona yardımcı olacak bir yaratıcının varlığını hissettirecektir. Yaratıcı ile insan arasındaki ilişki bir süre sonra ebeveyni ile çocuk veya 
öğretmen ile öğrenci arasındaki ilişkiye benzemeye başlayacaktır. Bu evreden sonra öğrenci veya çocuk konumunda olan insan hem kendisinin değer verdiği hem de kendisine değer veren öğretmen - ebeveyn konumundaki yaratıcıyı üzmemek adına onun isteklerine uymaya daha çok dikkat edecek ve onun için onun gözünde daha iyi bir insan olabilmek için eylemlerini ve duygularını istendiği şekilde sergilemeye başlayacaktır. Sonuç olarak insanların Tanrı ile iletişim kurma istekleri, kişileri Tanrı ile ilişki kurmaya ve bununla beraber Tanrı'nın istediği davranışları sergilemeye yönlendirir (Altıntaş, 1980, 175).

\subsection{Kişinin İbadetlerine Etkisi}

Beden ve ruh olmak üzere iki yönlü yaratılmış olan insanın bedeninin olduğu kadar ruhunun da gıdaya ihtiyacı vardır ve bu gıdayı kişi ibadetler ile sağlar (Şimşek, 2015, 151). İnandığı ve sevdiği varlığa ibadet etmek insanlar için en yüce zevk kaynağıdır (Demirci, 2016, 177). Kur'an' da kişilerin yaratılma sebepleri “Cin ve insanlar ancak bana ibadet etsinler diye yarattım" (ez-Zâriyât 51/56-58) şeklinde açıklanmaktadır. İbadetler sadece namaz, oruç, hac gibi vakti belirlenmiş olanlarla sınırlı değildir. Allah'ın inananlardan yapmasını veya yapmamasını istediği her şey ibadet kapsamına girmektedir (Şimşek, 2015, 153). Yani ibadet, sadece şekillerle sinırlı kalmayıp kişinin günlük yaşamında ve ahlaki davranışlarında samimi olarak sergilediği her şeyi kapsar (Şimşek, 2015, 157). Kişiyi negatif özelliklerinden arındırmak, ahlak sahibi, çevresi ile iyi ilişkiler içerisinde olan kişiler yetiştirmek, kişiyi Allah'a yakınlaştırmak amacıyla insanları değiştirmeye ve geliştirmeye çalışan din, inananlardan dua, namaz, oruç, zekat ve benzeri birtakım ibadetler ister (Kayıllık, 2014, 129).

Özel ibadetler dışında kalan ve gerçekleştirmek için kişilerin olumsuz duygularını kontrol etmeleri gereken genel ibadet olarak adlandırabileceğimiz konulara hırsızlık (elMâide 5/38-39; el-Mümtehine 60/12), giybet (en-Nisâ 4/148; el-Hucurât 49/12; el-Hümeze 104/1), zina (el-En'âm 6/151; el-İsrâ 17/32; en-Nur 24/30-31; el-Furkân 25/68; elMümtehine 60/12), cinayet (el-Bakara 2/178; en-Nisâ 4/29, 92-93; el-Mâide 5/32; el-En' âm 6/151; el-İsrâ 17/33; el-Furkân 25/68), fakirlik (el-Bakara 2/155; el-Fecr 89/16), iftira (elAl-i İmran 3/24, 94; en-Nisâ 4/20, 48, 50, 112; en-Nur 24/23-25; el-Hucurât 49/11-13) gibi başl1kları örnek olarak verebiliriz.

Sözlükte "mükellefin, rabbini yücelterek kendi nefsinin isteklerine karşı çıktığı filleri (Cürcani, 2003, 223)" olarak tanımlanan ibadet, çocukluk dönemlerinde taklit ile başlar ama aslında içten gelen duygularla yapılır ve çocuğun Allah ile içten bir ilişki kurmasını sağlar (K. Yavuz, 1983, 152).

Ribot, ibadetlerin din duygusunun yaşamdaki yansımaları olduğunu söylemektedir. Ona göre ibadetler psikolojik temellidirler ve gelişimler iki aşamada ele alınabilir. Ribot, ibadetlerin ilk aşamada doğrudan dini duyguyu yansıttığını ama ikinci aşamada hakikatten mecaza geçilmesi ile ibadetlerin artık sembol haline geldiğini söylemektedir (Ribot, 2014, 317).

Journal of Analytic Divinity, https://dergipark.org.tr/tr/pub/jad Volume 5/1 
İnsanlar, zamanla duygu dünyalarını kontrol altına aldıkları zaman ibadetlerini ve davranışlarını kendilerine gelen duyum ve algılar ile yapmaya ve bunun sonucunda huzur duymaya başlarlar. William James'in deyişiyle "Duygu, dindarlığın ilk ve en derin kaynağıdır. Allah'tan korku, Allah'a saygı ve bağlılık, Allah aşkı tamamen insana özgü psikolojik hallerdir" (Armaner, 1980, 115).

Kişiyi ibadet etmeye motive eden toplumsal ve bireysel bazı etkenler vardır. Bunlardan toplumsal olanlardansa bireysel olanlar kişi üzerinde daha etkilidir. Borç ödeme düşüncesi, ceza korkusu ve şükür gibi nedenler bazı bireysel motivasyonlardır. Bunlardan borç ödeme düşüncesi ve ceza korkusu kişinin gerçek tutum değişimini ortaya koymazken, şükür ödül ve ceza düşüncesinden tamamen bağımsız olarak ortaya çıkar. Şükürde kişi kendisine yapılan iyilik karşısında gönüllü olarak bir yakınlaşma sergiler. Bu sebeple kişi ibadetleri şükür mantığı ile yaptığı zaman Allah ile arasındaki yakınlaşma ve bağlılık artmaktadır. Bunun sonucunda ise birey kendisine yapılan iyiliğe iyilik ile karşılık vermeye ve Allah'ın istediği gibi bir insan olmaya yönelir (Karaca, 2015, 149-150).

Kişinin sergilediği ibadetin kalitesini içerisinde bulunulan zaman ve mekan gibi etkenler dişında bireyin fizyolojik ve psikolojik yapısı da etkiler (Karaca, 2015, 155). Örneğin kişi namaz (el-Bakara 2/43; en-Nisâ 4/103) ve hac (el-Bakara 2/196; el-Al-i İmran 3/97) gibi ibadetleri yerine getirdiği zaman sosyal sınıfların hiçbir öneminin olmadığı düşüncesine sahip olmakla beraber namazda gününü planlamayı, hac da ise sosyal ilişkiler kurabilmeyi öğrenirken, oruçta (el-Bakara 2/183) nefsini terbiye etmeyi, sadaka ve zekat (el-Bakara 2/43) ibadetlerini yerine getirdiği zaman ise kendini beğenmemesi, zayıfı ezmemesi ve en önemlisi maddeye köle olmaması gerektiğini anlar. Şükürde kişi sınırsız arzularına rağmen kulluk bilincini hatırlarken kanaatte ise, kişinin kazanma hırsı, diğer insanları kontrol etme gibi duygularını kontrol etmede çok etkilidir (Karaca, 2015, 156-157).

İbadetlerin özü olan dua ise bir nevi kul ile Allah arasındaki diyalogdur. Kul ihtiyaçlarını, arzularını dua aracılığıyla Allah'a iletir, ruhu ve kalbi ile Allah'la konuşur. Yani dua ile insan sürekli Allah ile iletişim içerisindedir (Erten, 2014, 220; Kayıklık, 2014, 129). Duanın İslam için ne kadar önemli olduğu Kur'an'ın dua ile başlayıp (el-Fatiha 1/57) dua ile bitmesinden (en-Nas 114/1-6) anlaşılabilir. Aynı zamanda "Duanız olmadiktan sonra Rabbim sizi ne yapsın?" (el-Furkan 25/77) ayeti insanların yaratılma amaçlarının dua olduğuna işaret etmektedir.

Yapılan bir araştırmaya göre insanların \%30'u gibi bir oranın sıkıntılı anlarında ve ihtiyaçları üzerine dua ettikleri bilinmektedir (Kayıklık, 2014, 145). Kişileri dua etmeye yönelten güdüler Kur'an' da temelde ihtiyaçlar ve istekler ile güçsüzlük ve çaresizlik olarak iki grupta ele alınır. İhtiyaç ve istek grubunda ele alınacak dualar dünya hayatı ile ilgili olanlar ve ahiret hayatı ile ilgili olanlar olmak üzere iki gruba ayrılabilir (Kayıklık, 2014, 132). Kişilerin dünya hayatı ile ilgili olarak yaptıkları dualara; çevresindeki 
ahlaksızlıklardan uzak durma (eş-Şuara 26/169), kötülük kışkırtma ve vesveselerden korunma (en-Nas 114/1-6; el-Felak 113/1-5), zalimlerin içinde kalmama (el-Mü'minun 23/94), düşmanlarına karşı yardım isteme (el-Bakara 2/286) gibi konular örnek olarak verilebilir. Kişinin ahiret hayatı ile ilgili olan duaları ise; bağışlanma (el-Al-i İmran 3/16; elA'raf 7/23, 149) ve doğru yoldan ayrılmama (el-Al-i İmran 3/8) gibi konular örnek olarak verilebilir. Bir diğer grup olan güçsüzlük ve çaresizlik ise çaresizlik karşısında yapılanlar (el-A'raf 7/94; el-Yunus 10/12; el-A'raf 7/126), darlık ve zorluk anında yapilanlar (elYunus 10/22; el-Lokmân 31/32) ve aniden ortaya çıkan zamanlarda yapılanlar (el-Enbiya 21/83; el-Kamer 54/10; eş-Şuara 26/169) olmak üzere üç grupta ele alınır.

Kişi yaratıcı ile arasındaki bağlılığı arttırdıktan, arasında duygusal bir bağ kurduktan sonra onun kendisinden istediği ibadetleri yerine getirirken daha hassas ve daha dikkatli davranır. Çünkü ibadetler değer verdiği bir yaratıcının kendisinden istediği eylemledir. Sonuçta ibadetler yaratıcının kullarından istediği buyruklardır kullar normalde bu buyrukları yerine getirmektedir. Fakat işin içine bir de yaratıcı ile kurulan duygusal bağ girdiği zaman her şey daha farklı olmaktadır. O zaman kişi ibadetlerini yerine getirirken yaratıcının kendisini daha çok sevmesi, yaratıcıyı memnun edebilme, yaratıcıya daha çok yakınlaşabilme, iyi bir kul olabilme ve öteki dünyada daha üstün olabilme gibi motivasyonlarla ibadetlerini daha samimi ve özenli yerine getirir.

İbadetler, içerisinde heyecan ve duygusal tecrübeler barındıran, bireysel olduğu kadar toplumsal da olan fillerdir. Bu özellikleri göz önüne alındığı zaman ibadetlerin psikososyal duygusal tecrübeler olduğunu söyleyebiliriz. Bu sebeple bireylerin dini duyguları sadece kendi yaşamlarını değil içlerinde bulundukları toplumla da etkileşim içerisindedir. Yani bireyin dini yaşantısı hem toplumu etkiler hem de toplumdan etkilenir (Koçak, 2016, 34-35). Çünkü dinlerin insanları bütünleştirici bir etkisi vardır ve bu etki en açık şekilde İslam'da görülür (Güngör, 2007, 190).

\subsection{Kişinin Toplumda Kendini Doğru İfade Edebilmesi}

İnsanlığın temel unsurlarından olan, insanların gerek kendileriyle gerek çevreleriyle olan iletişimlerini ve aralarındaki bağı oluşturan duygular; insanların yaşamı anlamlandırmalarında, karar vermelerinde, hayatlarını devam ettirmelerinde, verdikleri tepkiler ve sergiledikleri davranışlar üzerinde akıldan daha fazla etkilidir. Kişi ne kadar farkında olmasa da günlük hayattaki olaylara verdikleri tepkiler, ruh halleri ve performansları hissettikleri duygularla alakalıdır. $\mathrm{Bu}$ sebeple insanlar kendilerini duygulardan tamamen soyutlayamaz fakat duygularını kontrol altına alarak onları istediği şekilde yönlendirebilir ve hayatlarından daha fazla verim almayı sağlayabilirler. Bununla beraber unutulmamalıdır ki duygular rastgele ortaya çıkmış şeyler değildir. Belirli süreçler sonucunda meydana gelmişlerdir ve insanların hayatlarını sürdürebilmeleri için gereklidir. Geçmiş dönemlere baktığımız zaman insanların hissettikleri duygular sayesinde kendilerini koruyabildikleri, avlanabildikleri ve hayatta kaldıkları söylenebilir.

Journal of Analytic Divinity, https://dergipark.org.tr/tr/pub/jad Volume 5/1 
İlk başta bu şekilde insanların hayatta kalmalarını sağlayan duygular zamanla değişime uğrayarak sosyal bir varlık olan insanın diğer insanlarla olan ilişkilerini düzenleyen normların ve rollerin kaynağı haline gelmiştir. İnsanların duygularını bu sebeple de davranışlarını şekillendiren, bunların sınırlarını belirleyen temel etken kişinin ve kişinin içinde bulunduğu toplumun düşünceleri, normları ve rollerdir. İnsanın davranışları içsel olarak hissettiği duygular sonucunda olabileceği gibi toplumun kendisine belirlediği normlar ve rollerden dolayı dışsal da olabilir. Gerçekte duygular aynı olmakla beraber kültür, yaş, cinsiyet, meslek, toplumun kişiye belirlediği normlar ile rollere uygun davranmak ve toplum tarafından kabul görebilmek için duygularını kontrol etmek zorundadir.

Duyguların ifade ettikleri şeyler kişiden kişiye ve toplumdan topluma değişebilmektedir. Her duygu her toplumda aynı şeyi ifade etmediği için kişinin sosyal çevresinden kabul görebilmesi sebebiyle içinde bulunduğu toplumun normlarına ve toplumun kendisine belirlediği rolün getirilerine uygun davranması ve duygularını bunlara göre ifade etmesi, yaşaması gerekir. Kişiler her ne kadar yanlış da olsa kabul görebilmek için genellikle duygularını bastırırlar. Ama eğer kişinin farkındalığı yüksekse ve kişi hangi düşünce sonucunda hangi duygunun kendinde ortaya çıtığını biliyorsa duygularını kontrol ederek duruma müdahil olabilir (Gençoğlu ve Yılmaz, 2013; Voltan Acar, 2013, 55; Yalçın, 2010).

İnsanlar birbirleriyle olan sosyal ilişkilerinin yönlerini sergiledikleri tutum ve davranışlar ile belirlemektedir. Sergiledikleri davranışların nasıl olacağı ise ahlaki sisteme bağlıdır. Ahlaki kuralların kaynağı; insanların hayatını düzenleyen kanunların ve insani görevlerin de kaynağı olan dindir (Babanzâde, 2004, 22). Ahlaki değerlerin korunması, kişinin içinde bulunduğu toplumla sağlıklı ilişkiler kurabilmesi ve toplumun huzurunun sağlanması gibi pek çok konuda dinin ve dindarlığın çok önemli işlevleri vardır (Yapıcı, 2005, 59). Toplumsal yapılarda ahlaki değerlerin korunmasını sağlayan dinler, aynı zamanda bireylerin sosyal uyum sağlamaları üzerinde de etkilidir (Hökelekli, 2005, 118119).

Bireyin çocuklukta ebeveynleri ve öğretmenleri vasıtasıyla öğrendiği davranış kuralları ile kişi sosyal öğrenmeye ve bu şekilde ahlaki sistemini oluşturmaya başlar. İlk etapta aileden daha sonra toplumdan öğrenilen ahlaki kazanımlar, kişilerin bireysel ve sosyal alanda davranışlarını dolayısıyla da duygularını kontrol etmesine yol açar.

Toplumların iyi olması için ilk başta bireylerin iyi olması gerekir. Bu sebeple dinler bireylerle olduğu gibi bireylerin içerisinde yaşadığı toplumlarla da ilgilenmişlerdir. Kişilerin ahiret hayatını önemsediği kadar kişilerin dünya hayatını da önemsediğinden dolayı Kur'an-1 Kerim içerisinde toplumlar için hem ahlakla ilgili konulara hem emir ve yasaklara hem de cezalara yer vermiştir (Şimşek, 2015, 179). Kur'an aile kurumu dişında 
toplumla ilgili diğer konularda çok ayrıntıya girmemiştir. Ve İslam toplumunun genel olarak vasat/orta (el-Bakara 2/143), hayırlı (el-Al-i İmran 3/110) ve birlik içinde (elMü' minun 23/52) olan bir toplum olduğunu söylemiştir.

İslam toplumunun hayırlı bir toplum olması için Kur'an'da onlara belirlenen sınırlara bakacak olursak öncelikle; Kur'an'ın indiği dönemde gerek dine dayalı gerek beşeri hukukların hepsinde yasal bir kurum olan köleliği İslam, getirmemiş hatta tamamen kaldırmasa bile sınırlarını belirlemiş ve köleliğin kaynağını savaşla sınırlı tutmuştur (Şimşek, 2015, 199). Aynı zamanda kölelerin özgür olabilmeleri için birçok imkân sunmuştur (eş-Şems 91/11-13; en-Nur 24/33). Kur'an' da toplumla ilgili belirlenen bir diğer konu ise etnik köken yani ırkçılıktır. Kur'an her türlü ırkçılığ1 reddetmiş ve kişinin de etnik kökeninden ayrı bireysel olarak değerlendirilmesi gerektiğini (en-Necm 53/36-40; el-İsra 17/15) söylemiştir. Kişiler için geçerli bu düşüncesini gruplar için de geçerli kılmış ve İslam'ın indiği zamanki toplumda çok yaygın olan kavmiyetçiliği kaldırmıştır (el-Hucurat 49/13).

İnsanların davranışlarının sınırlarını belirleyen Kur'an-ı Kerim aynı zamanda onların istenmeyen davranışları sergiledikleri zaman ne ile muhatap olacaklarını da belirlemiş ve Peygamberine "insanlar arasında Allah'ın sana gösterdiği şekilde hüküm veresin" (en-Nisâ 4/105) buyruğuyla da bildirtmiştir. İnsanlardan istediklerini ise "Allah adaleti, ihsanı, akrabaya vermeyi emreder. Edepsizlikten, kötülükten ve azgznlıktan meneder. Öğüt almanız için size böyle öğüt verir." (en-Nahl 16/90) şeklinde bildirmiştir. İnsanların yapmamaları istenen ve yaptıkları zaman karşılı̆̆ını bulacakları adam öldürme (el-Maide 5/32), hırsızlık (el-Maide 5/38-40), zina (en-Nisâ 4/15-16; en-Nur 24/2), iffetli kadınlara iftira atma (en-Nur 24/4-5), yetime kötü davranma (ed-Duhâ 93/9) ve fesat çıarma (el-Maide 5/33-34) gibi konular Kur'an'da yer almaktadır.

Hukuk ile ilgili konularda bu şekilde sınırlar belirleyen Kur'an kişilere ahlak ile ilgili de bir sınır çizmiştir. Bu sınırlar sadece kişinin Allah'a karşı olan ahlaki sorumlulukları ile sınırlı değildir. Kur'an aynı zamanda kişilerin içerisinde yaşadığ karşı da ahlaki sorumluluklarını bildirilmiştir (Demirci, 2016, 255). Bu sorumluluklar iyiliğe yöneltip kötülükten uzaklaştırmak (el-Al-i İmran 3/104, 110), ana-baba ile yetimlere iyi davranmak (el-Bakara 2/83, 177,215), din ve kan kardeşleriyle iyi geçinmek (el-Hucurât 49/10) olarak örneklendirilebilir.

\section{Sonuç}

İnsanların doğdukları ilk andan hayatlarının son anına kadar her zaman onlarla beraber olan, yaptıkları her eylemde farklı şekillerde hissedilen duygular, kişilerin hem içerisinde bulunduğu ruh halini hem kişinin motivasyonu ile enerjisini hem de sergileyeceği davranışları üzerinde etkilidir. Kişinin duyguları ve davranışları karşılıklı etkileşim halindedir. Kişinin hissettiği duygular sergileyeceği davranışları etkilediği gibi 
sergilediği davranışları da içinde bulunduğu duygu durumunu etkiler. Aynı zamanda duygular kişinin sadece içinde olduğu zamandaki duruma göre şekillenmezler. Duyguların hafızası vardır ve duygular geçmişte yaşanan herhangi bir olaya benzer bir olay yaşandığı zaman o duygu haline girebilir ya da kişi geçmişte sergilediği bir davranışı sergilediği zaman geçmişte hissettiği duyguları hissedebilir. Kişinin tehlikeli gördüğü durumlarda onu harekete geçiren duygu kişilerin yaşamları üzerinde çok etkilidir. Hatta ilk çağlarda insanlar duyguları sayesinde hayatta kalmış ve yaşamlarını devam ettirmişlerdir.

Kişiler üzerinde bu kadar etkili olan duygular kontrol altına alınmayıp bastırıldığı veya görmezden gelindiği zaman yok olmaz daha sonra fırsatını buldukları bir anda yön değiştirmiş bir şekilde ortaya çıarlar. Bu sebeple kişiler hayatlarının her alanında etkili olan duygularını görmezden gelmek yerine onları tanımalı, kontrol etmeyi öğrenmeli ve duyguları kişileri değil kişiler duygularını kontrol etmelidir. Hayatı neredeyse tamamen duygular üzerine kurulan insanın duyguları hakkında Kur'an-1 Kerim'de görüş bildirmiş ve bu alana müdahil olmuştur.

Kur'an-1 Kerim muhatap aldığı insanların hayatlarına ahlak, hukuk, ibadet, eğitim gibi pek çok alanda müdahale etmiş ve bu alanlarla ilgili onlara yapıp yapmayacakları veya hangilerini yapmalarının daha doğru olacağı ile ilgili birer çerçeve belirlemiştir. İnananlardan beklenilen ise bu çerçevelere uygun olarak yaşamalarıdır. Kur'an'ın belirlediği çerçeveler çoğu zaman ceza-ödül mantığı ile işlemektedir. Çünkü kişiler cezalandırılacaklarını bildikleri davranışları daha kolay bırakır ve ödüllendirilecekleri davranışlara daha kolay yönelirler. Bu alanda kişilere sunulan motivasyonlardan birisi de ahiret hayatıdır. Kişi bu dünyada yaptığı iyi veya kötü her şeyin karşılığını ahirette alacağı düşüncesi ile kendisinden istenilenleri yapmaya daha çok dikkat eder. Kişilerin hayatlarının her anında ve yaptıkları her eylemde duyguları onlarla beraberdir ve onları yönlendirir. Bu sebeple Kur'an'ın belirlediği çerçeveler arasında hem doğrudan kişilerin olumsuz duygularına hitap eden hem de dolaylı olarak kişilerin eylemlerine müdahale etmesi ile olumsuz duygularını kontrol eden emirler bulunmaktadır.

Kur'an tarafından kişilerin duygularına müdahale edildiğinin en temel göstergelerinden birisi kişinin yaratıcı ile arasında kurduğu bağlılıktır. Kişinin fıtratında var olan birisine güvenme ve inanma isteği bebekliğinden beri belirli şekillerde tezahür ettikten sonra kişi belli bir olgunluğa gelince bu ihtiyacını gidermek amacıyla tanrıya yönelir ve bu yönelme ile birlikte tanrı ile arasında duygusal bir bağ kurar. Bu duygusal bağlanma sonucunda hem davranışlarını hem de duygularını kendinden istenilen biçimde şekillendirir. Kişi davranışlarını istendik yönde şekillendirdiği zaman aslında duygularını da kontrol etmektedir. Çünkü kişilerin davranışlarının temelinde duyguları bulunmaktadır. Kişinin sergilediği ibadetler de davranışları içerisinde değerlendirilebilir. Kişi bu ibadetleri bazen ödül-ceza motivasyonu ile yaparken bazen de güvendiği ve sevdiği 
yaratıcıyı memnun etmek ve onun istediği gibi birisi olmak amacıyla tamamen duygusal olarak yapar.

Kişinin ibadetleri dışında sergilediği davranışlar da Kur'an'ın yani yaratıcının ondan istediği biçimde şekillendiği için bu durum kişinin içerisinde yaşadığı sosyal çevreyle olan ilişkilerini de etkiler. Kur'an hem bireylere hem de bireylerin içerisinde yaşadıkları toplumlara hitap etmiştir. Bundan dolayı içerisinde toplumsal düzen ile ilgili pek çok başlıkta pek çok bilgi, istek, emir ve yasak mevcuttur. Bunlar kişilerin çevresine nasıl davranması gerektiği, aileden başlayarak içerisinde bulunduğu grup ve kuruma karşı olan sorumlulukları, toplum içerisinde istenilen dışında yani toplum düzenini bozacak şekilde davranıldığında ne olacağı ile ilgili konulardır. Kur'an bu şekilde kişilerin olumsuz duyguların kontrol ederek onların hem daha iyi inananlar hem de daha iyi insanlar olmasını hedeflemiştir.

Sonuç olarak Kur'an-1 Kerim kişilerde doğuştan var olan güvenme isteğinin Allah'a yönelmesi ile kurulan bağlılık ve bu bağlılı̆̆ın getirileri olan kişilerin sergiledikleri ibadetler ve topluma karşı davranışları gibi pek çok konuda kişilerin olumsuz duygularını kontrol etmekte ve böylece onların davranışlarını da şekillendirmektedir.

\section{Kaynakça}

Abdullah, Che Haslina vd. "Emotional Management Skill at Work Place: A Study at Government Department in Seberang Perai Tengah". International Journal of Social Science and Humanity $3 / 4$ (2013), 365-368.

Acar, Ergül. İşletme Yönetiminde Duygusal Zekânın Yeri ve Önemi Üzerine Bir Araştırma. Hatay: Mustafa Kemal Üniversitesi Sosyal Bilimler Enstitüsü, Yüksek Lisans Tezi, 2007.

Akça Erdoğan, Bahar. Okul psikolojik Danışmanlarının (Rehber Öğretmenlerinin) Kullandıkları Mizah Tarzlarına Göre Duygu Yönetimi Becerilerinin ve Psikolojik İyi Oluşlarının İncelenmesi. Bolu: Abant İzzet Baysal Üniversitesi Eğitim Bilimleri Enstitüsü, Yüksek Lisans Tezi, 2018.

Allen, R. E. (ed.). The Concise Oxford Dictionary of Current English. 383. America: Oxford Universty Press, 1990.

Altıntaş, Hayrani. "Din Psikolojisi ve Tasavvuf". İslam İlimleri Enstitüsü Dergisi 4 (1980), 171-197.

Altıntaş, Hayrani. "İslam'da Mesuliyet Duygusu”. Diyanet Dergisi 19/2 (1983), 1420.

Armaner, Neda. Din Psikolojisine Giriş. Ankara: Ayyıldız Matbaası, 1980.

Atay, Hüseyin. Kur'an’a Göre Iman Esasları. Ankara: Ajans-Türk Matbaası, 1961.

Journal of Analytic Divinity, https://dergipark.org.tr/tr/pub/jad

Volume 5/1 
Atış, Naciye. "Spinoza Felsefesinde Beden ile Zorunlu Birlik İçerisindeki Ruhun Gücü”. Felsefe ve Sosyal Bilimler Dergisi 20 (2015), 143-160.

Avc1, Nevin. Okul Müdürlerinin Duygu Yönetimi Yeterliklerinin Çeşitli Değişkenlerle İncelenmesi ve Kişilik Özellikleri ile İişkisi. Kocaeli: Kocaeli Üniversitesi Sosyal Bilimler Enstitüsü, Yüksek Lisans Tezi, 2014.

Aybatan, Kemal. Çalışanların Proaktif Kişilik Özellikleri ile Duygu Yönetimleri Arasındaki İişkinin İncelenmesi. İstanbul: İstanbul Gelişim Üniversitesi Sosyal Bilimler Enstitüsü, Yüksek Lisans Tezi, 2018.

Babanzade, Ahmed Naim. İslam Ahlakının Esasları. İstanbul: Bedir Yayınevi, 2004.

Baltaş, Zuhal. İnsanın Dünyasını Aydınlatan ve İşine Yansıyan Işık Duygusal Zeka. İstanbul: Remzi Kitapevi, 2006.

Bekman, Müge. Duygu Yönetimi Açısından Uçuş Personeli ve Yolcu Iletişimi. İstanbul: Marmara Üniversitesi Sosyal Bilimler Enstitüsü, Yüksek Lisans Tezi, 2016.

Bergson, Henri. Ahlak ile Dinin İki Kaynağı. çev. Mehmet Karasan. Ankara: Milli Eğitim Basımevi, 1962.

Beyhan Mayda, Melek. Genel Psikolojik Sağlığın Yordayıcıları Olarak Duyguları Yönetme Becerileri ve Çocukluk Çağı Örselenme Yaşantıları. Muğla: Muğla Sitkı Koçman Üniversitesi Eğitim Bilimleri Enstitüsü, Yüksek Lisans Tezi, 2017.

Bolay, Hayri Süleyman. "Kişide Güven Duygusu ve İslam”. Kutlu Doğum Haftası Konferansları. 159-161. Ankara: Türkiye Diyanet Vakfı Yayınları, 1989.

Bovet, Pierre. Din Duygusu ve Çocuk Psikolojisi. çev. Selahattin Odabaş. Ankara: Türk Tarih Kurumu Basımevi, 1958.

Cüceloğlu, Doğan. İnsan ve Davranışı. İstanbul: Remzi Kitapevi, 1997.

Cürcani, Seyyid Şerif. Kitâbu't-Ta'rifât. Beyrut: Dâru'n-Nefâis, 2003.

Çakar, Ulaş - Arbak, Yasemin. "Modern Yaklaşımlar Işığında Değişen Duygu-Zeka İlişkisi ve Duygusal Zeka”. Dokuz Eylül Üniversitesi Sosyal Bilimler Enstitüsü Dergisi 6/3 (2004), 23-48.

Çeşitçioğlu, Mustafa. Kaliteli İnsan. İstanbul: Alfa Yayınları, 2003.

Çetinkaya, Bayram. Türkiye Türkçesinde Mutluluk ve Üzüntü Göstergeleri. Ankara: Gazi Üniversitesi Sosyal Bilimler Enstitüsü, Doktora Tezi, 2006.

Çoruk, Adil. Yönetim Süreçleri Açısından Yöneticilerin Duygu Yönetimi Davranışları. Çanakkale: Çanakkale Onsekiz Mart Üniversitesi Eğitim Bilimleri Enstitüsü, Doktora Tezi, 2012. 
Demirci, Muhsin. Kur'an'ın Ana Konuları. İstanbul: M.Ü. İlahiyat Fakültesi Vakfı Yayınlar1, 2016.

Dodurgalı, Abdurrahman. Eğitim Sosyolojisi. İstanbul: M.Ü. İlahiyat Fakültesi Yayınları, 1995.

Durmuşoğlu Saltalı, Neslihan. Duygu Eğitiminin Okul Öncesi Dönem Çocuklarının Duygusal Becerilerine Etkisi. Konya: Selçuk Üniversitesi Sosyal Bilimler Enstitüsü, Doktora Tezi, 2010.

el-Isfehani, Ragıb. Müfredatu elfazi'l-Kur'an. 456. Dımaşk: Daru'l Kalem, 1997.

Erten, Mevlüt. "Kur'an'da Murâkabe ve Münafiklar". Turkısh Studıes International Periodical For The Languages, Literature and History of Turkish or Turkic, 207231.

Fichter, Joseph H. Sosyoloji Nedir. çev. Nilgün Çelebi. Ankara: Anı Yayıncılık, 2016.

Frijda, Nico H. - Mesquita, Batja. "Beliefs Through Emotions". Emotions and Beliefs: How Emotions Influence Thought. 45-77. Cambridge University Press, 2000 .

Gençoglu, Cem - Yılmaz, Müge. "Duygusal Farkındalık Eğitim Programının Duygu Kontrol Düzeyine Etkisi”. International Journal of Social Science 6/5 (2013), 961-980.

Goleman, Daniel. Duygusal Zeka Neden IQ'dan Daha Önemlidir? çev. Banu Seçkin Yüksel. İstanbul: Varlık Yayınları, 2016.

Gözütok, Şakir. "Çocukta Dini ve Ahlâki Duyguların Eğitimi”. Çocuk Sorunları ve İslâm Sempozyumu. 797-807. İstanbul: Nesil Matbaacıllk, 2010.

Günay, İlhami. "Kur'ân-1 Kerîm'de Gençlerin Duygu Gelişimi ve Eğitimi”. Turkısh Studies International Periodical For The Languages, Literature and History of Turkish or Turkic 10/2 (2015), 435-460.

Güney, Salih. "Duygu, Çekicilik, Sevgi, Yakınlaşma, Aşk, Öfke ve Saldırganlık". Sosyal Psikoloji. 104-141. Erzurum: Atatürk Üniversitesi Aç1köğretim Fakültesi Yayını, 2021.

Güngör, Erol. Ahlak Psikolojisi ve Sosyal Ahlak. İstanbul: Ötüken Neşriyat, 2000.

Güngör, Özcan. "1.5 ve 2. Nesil Türk Gençlerinin Ailede Dini Sosyalleşmeleri: New Jersey, USA Örneği”. Ankara Üniversitesi İlahiyat Fakültesi Dergisi 53/2 (2012), 85-119.

Güngör, Özcan. “Kur’an'da Sosyal Bütünleşme”. Diyanet İlim Dergi 43/2 (2007), 173-190.

Han, Tekin. Kur'an ışığında Duyguların Eğitimi. Iğdır: Iğdır Üniversitesi Sosyal Bilimler Enstitüsü, Yüksek Lisans Tezi, 2017. 
Hökelekli, Hayati. Din Psikolojisi. Ankara: Türkiye Diyanet Vakfı Yayınları, 2005.

Isfehani, Ragıb el-. Müfredatu elfazi'l-Kur'an. 456. Dımaşk: Daru'l Kalem, 1997.

İşeri, Büşra. Üniversite Öğretim Elemanlarının Duygu Yönetimi Yeterlikleri. Kırşehir: Kırşehir Ahi Evran Üniversitesi Sosyal Bilimler Enstitüsü, Yüksek Lisans Tezi, 2019.

Karaca, Faruk. Din Psikolojisi. Trabzon: Eser Ofset Matbaac1lık, 2015.

Karaca, Faruk. "İnsanın Bazı Güdü ve Duygularının İslâmî Açıdan Değerlendirilmesi”. Ekev Akademi Dergisi 1/1 (1997), 159-172.

Karakaş, Ayhan. "Duygusal Emek, Tükenmişlik ve İşten Ayrılma Niyeti Arasındaki İlişki: Otel İşletmesi Çalışanları Üzerine Bir Araştırma”. İşletme Araştırmaları Dergisi $9 / 1$ (2017), 80-112.

Karaman, Hayreddin vd. Kur'an Yolu Türkçe Meal ve Tefsir. V Cilt. Ankara: Diyanet İşleri Başkanlığı Yayınları, 2012.

Kasapoğlu, Abdurrahman. "Kur'an'a Göre Dinin Toplumsal Bütünleşmedeki Rolü". Hikmet Yurdu Düşünce-Yorum Sosyal Bilimler Araştırma Dergisi 9/17 (2016), 21-116.

Kayıklık, Hasan. Din Psikolojisi Bireysel Dindarlık Üzerine. Adana: Karahan Kitabevi, 2014.

Kervanc1, Ferda. Büro Çalışanlarının Duygu Yönetimi Yeterlilik Düzeylerinin Geliştirilmesinde Duygu Yönetimi Eğitimi Programının Etkisi. Ankara: Gazi Üniversitesi Eğitim Bilimleri Enstitüsü, Yüksek Lisans Tezi, 2008.

Kirkpatrick, Lee A. "Din Psikolojisinde Bağlanma Teorisi”. çev. Mustafa Koç. Bilimname Dergisi 10/1 (2006), 133-172.

Koçak, Ali. Duygular ve Din Duygusu. Adana: Çukurova Üniversitesi Sosyal Bilimler Üniversitesi, Yüksek Lisans Tezi, 2016.

Konrad, Stefan vd. Duygularla Güçlenmek. İstanbul: Hayat Yayıncılık, 2003.

Kuşeyri, Abdulkerim. Kuşeyri Risalesi. çev. Süleyman Uludağ. İstanbul: Emek Matbaac1lık, 1999.

Mehmedoğlu, Yurdagül. Ahlâkî ve Dinî Gelişim. İstanbul: Morpa Kültür Yayınları, 2005.

Özdemïr, Emine. Duygu Yönetimi Eğitim Programının AVM Çalışanlarının Duygularını Yönetme Beceri Düzeylerine Etkisi. Mersin: Toros Üniversitesi Sosyal Bilimler Enstitüsü, Yüksek Lisans Tezi, 2017.

Özdemir Yaylac1, Gaye. Kariyer Yaşamında Duygusal Zeka ve İetişim Yeteneği. İstanbul: Hayat Yayınc1lık, 2006. 
Özer, Zuhal. "Üniversite Sinavına Doğru Sınav Kaygısıyla Başederken”. Bilim ve Teknik Dergisi, 76-77.

Pak, Süleyman. “Kur'an'ın Duyguları Eğitmesi Bağlamında Öfkenin Kontrolü Meselesi”. C.Ü. İlahiyat Fakültesi Dergisi 16/1 (2012), 69-103.

Payot, Jules. Irade Terbiyesi. çev. Hakan Alp. İstanbul: Ediz Yayınevi, 2019.

Peker, Hüseyin. Din Psikolojisi. İstanbul: Çamlıca Yayınları, 2003.

Pelit, Elbeyi vd. "Duygusal Zekânın İletişim Becerilerine Etkisi: Turizm Öğrencileri Üzerinde Bir Araştırma”. Dokuz Eylül Üniversitesi Sosyal Bilimler Enstitüsü Dergisi, 85-107.

Ribot, Théodule. "Dini Duygu". ed. Figen Kasapoğlu - Mustafa Şekip Tunç. Hikmet Yurdu Düşünce-Yorum Sosyal Bilimler Araştırma Dergisi 7/13 (2014), 303321.

Robbins, Stephen P. - Judge, Timothy A. "Duygular ve Duygu Durumlar". çev. Hayat Ebru Erdost Çolak. Örgütsel Davranış. 98-131. Ankara: Nobel Akademik Yayınc1lık, 2012.

Sert, Hüseyin Emin. "Kur'an-1 Kerim Işığında Güven Duygusunun Kaynağı Olarak Müslümanlık Bilinci”. İlahiyat Fakültesi Dergisi 13/2 (2008), 197-225.

Şimşek, M. Sait. Kur'an'ın Ana Konuları. İstanbul: Beyan Yayınları, 2015.

Tarhan, Nevzat. Duyguların Dili. İstanbul: Timaş Yayınları, 2010.

TDK. Türkçe Sözlük. 580-581. Ankara: Türk Dil Kurumu Yayınları, 2005.

Tuna, Yavuz. "Duygular". Birey ve Davranışı. 20-40. Eskişehir: Anadolu Üniversitesi, 2018.

Türk, Esra. "Çocukluk Döneminde Duygusal Gelişim ve Din Eğitimi”. Marifet Divanı Araştırmalar Dergisi 14/3 (2014), 143-158.

Uludağ, Süleyman. İslâm Düşüncesinin Yapısı. İstanbul: Dergah Yayınları, 1985.

Ülken, Hilmi Ziya. Sosyoloji Sözlüğü. 88. İstanbul: Milli Eğitim Basımevi, 1969.

Voltan Acar, Nilüfer. İnsan İiş̧kileri İletişim. Ankara: Nobel Akademik Yayıncılık, 2013.

Vural, Faruk. "Yusuf Suresi Bağlamında Kıskançlık Haset Duygularına Psikolojik Bir Yaklaşım”. Dicle Üniversitesi İahiyat Fakültesi Dergisi 13/2 (2011), 127152.

Yalçın, S Barbaros. Üniversite Öğrencilerinin Duygularını Ífade Edebilmelerinin Aleksitimi ve Psikolojik İhtiyaçlarına Göre İncelenmesi. Konya: Selçuk Üniversitesi Eğitim Bilimleri Enstitüsü, Doktora Tezi, 2010. 
Yapıc1, Asım. "Fiziksel ve Sosyal Hadiselere Sebep Atfetmede Dinin Rolü". Ç.Ü. İlahiyat Fakültesi Dergisi 3 / 1 (2003), 127-165.

Yapıcı, Asım. İslam'da Tövbe ve Dinî Yaşayıştaki Rolü. İstanbul: Beyan Yayınları, 1997.

Yapıcı, Asım. Ruh Sağlığı ve Din: Psiko-Sosyal Uyum ve Dindarlık. Adana: Karahan Kitabevi, 2013.

Yavuz, Kerim. Çocukta Dinî Duygu ve Düşüncenin Gelişmesi. Ankara: Diyanet İşleri Başkanlığı Yayınları, 1983.

Yavuz, Yusuf Şevki. Kur'ân-ı Kerîm'de Tefekkür ve Tartışma Metodu. İstanbul: İlim ve Kültür Yayınları, 1983.

Yazıc1, Asl1. "William James'in Descartes'in Duygu Kuramına Eleştirisi”. Araştırma Ankara Üniversitesi Dil ve Tarih-Coğrafya Fakültesi Felsefe Bölümü Dergisi, 117.

Yeğin, Hüseyin İ. “Öfke Duygusu ve Dinî Açıdan Baş Edebilme Yolları”. Dinbilimleri Akademik Araştırma Dergisi 10/2 (2010), 235-258.

Y1lmaz, Ömer. Geçmişten Günümüze Tasavvuf ve Tarikatlar. Ankara: Akçağ Yayınlar1, 2019. 